\title{
FRAMING OF IDENTITY AND PERSONAL HISTORY THROUGH MULTIPERSPECTIVE NARRATIVES IN ATWOOD'S THE BLIND ASSASSIN
}

\begin{abstract}
Margaret Atwood's The Blind Assassin (2000) is an engagement in layers of shifting identities and their eventual unravelling. The novel is dominated by the character and voice of Iris Chase, an octogenarian who slowly and fumblingly presents to the reader the fragmented and complex personal history of her family. The novel becomes an exercise in historiography through Iris's visitations to her and her sister Laura's youth in order to explain their tenuous relationship which is achieved through three parallel sources: Iris's own attempts at a memoir, journalistic documents and letters from the past, and excerpts from an infamous novel published forty years previously. My paper will explore the three narrative structures present in the novel, and attempt to understand the questions of authorship and writing, and their importance in building a historiographic narrative. It will try to examine the ways in which retrospective interventions into public history helps to counter and create identities which were hitherto repressed under social decorum. This paper will borrow from Linda Hutcheon's writings of the postmodern metanarratives in order to compose a lucid understanding of what alternative historiography in literature can achieve, keeping at the centre Atwood's novel.
\end{abstract}

Keywords: historiography; metanarratives; writing; personal history.

Readers of The Blind Assassin are confronted with the problem of narration and identity from the very first page of the novel. The first segment ${ }^{1}$ of the novel opens to Iris recounting her sister's death, followed by a newspaper article announcing the same, whereas the second segment opens into the text of the

\footnotetext{
* Department of Literature and Languages of the World; University of Montreal.

1 The novel is divided into fifteen (XV) segments, which are further divided into smaller titled chapters.
} 
embedded narrative of The Blind Assassin. These shifts set stage for multiple narrative voices and a non-linear structure that tosses the readers into an unstable scripting of historiography. The novel is at once the memoir of Iris Chase, a reading of Laura Chase's infamous novel, and a collage of journalistic documents and letters from forty years ago. Personal history is featured as an invaluable source of historiographic material in the novel: Atwood interweaves social history with revelations about the life of Iris and her family and gives the readers an insight into the ways people respond to socio-political shifts in communities. By juxtaposing records from traditional sources of history (several important details in the plot are exposed to the readers through excerpts from newspapers) against Iris's memoir Margaret Atwood destabilises the authority of public knowledge around the socially prominent figures of the Chase and the Griffins. The novel's engagement with historiography is closely linked to its use of multiple narrative frameworks to push forward various timelines. The reader encounters a multiperspective method of storytelling which also complicates questions of agency and identity along with that of history. This paper will attempt to read the novel as an exercise in alternative, personal historiography which destabilises traditional accounts of record keeping and history writing. It will study the four different narrative frameworks the novel offers and examine how they influence this creation of personal historiography. It will also explore how Iris's writing of the memoir helps her to retrospectively shape her identity and claim ownership of her own creation.

The analysis of The Blind Assassin is incomplete without comments on the unique texture of the narrative style adopted by Atwood. Constant oscillation between the four narrative frameworks appears to be the most striking feature of the novel upon a preliminary read. Atwood avoids long chapters of continuous prose, instead the text is composed of smaller, compact titled chapters which break up the pace of reading and produce a sense of relentless movement in the reader. The shift between two titled chapters is often abrupt and Atwood deliberately does not provide sufficiently rounded endings to the chapters: often leading to the reader becoming confused. This is further heightened when two chapters refer to two separate narrative platforms or periods of time (for ease of writing I will refer to the narrative frames as units ${ }^{2}$ ). This makes the non-linearity

\footnotetext{
2 The term unit here refers to one of the four narrative frames or time frames the novel operates within.
} 
of the narrative structure very evident and helps to break up the traditional pace on forward progression. Writing about feminist authors subverting linear narratives, Brian Richardson makes note of the several methods which have been adopted to achieve the same. He speaks of reverse chronological linearity, prolonged causal progressions, and also reflects on how time passes at slower or faster than normal in certain narratives (Richardson 687, 688). Many of these methods can be found in Atwood's novel, residing consecutively and adding new layers to the already shifting framework.

The chapter entitled "The Toronto Start, 1945" is the first of many that are composed of newspaper excerpts. It announces the news of Laura Chase's death and sets the mood of the novel even as it does not divulge any related information. The newspaper excerpts produced throughout the novel are presented abruptly, often without subsequential chapters explaining their importance. Written in the classic disengaged, third person narrative voice of news articles, these units stand out against Iris's narrative point of view. True to conventional newspaper articles, these units are furnished with dates, references to locale or place of reporting, and the opinions of the reporter regarding the piece shared. This particular unit in itself does not follow a chronological sequence, often moving between years, even decades, thereby creating a sense of foreboding or partial knowledge in the reader. This narrative framework creates the backdrop against which the two central units of the novel play out. Iris Chase, who may be labelled as the central narrator of the novel occupies a dominant position in these two units. Iris's octogenarian self resides in the late 1990s but writes of an era from before her birth to her middle age. Iris's memoir straddles both spaces: her past which she writes about, and her present where she writes from. Both units have similar approaches to temporality and progression: both are linear narratives and Iris's life appears to move forward at an acceptable pace. There is considerable overlap between the two units as Atwood uses the flashback device in order to move from the present to the past. The transitions occur seamlessly and often the reader does not recognize the moments when the change of time frame takes place. What makes these two units unique and similar is the unreliable narrator in Iris. The unit dealing with the present makes the reader aware of certain incidents and situations from the onset (Iris leading a lonely life with no kin to support her) however, the unit from the past does not readily present the explanations for those situations. The newspaper articles coupled with Iris's current condition pushes the reader to find 
a justification in the past, which is not provided until the novel reaches its concluding chapters. It also appears as if the Iris from the present consciously delays writing about the pivotal incidents of her past. This incongruity could be a result of Atwood's desire for heightened tension and suspense in the narrative. It could also be an emulation of the physical and mental processes Iris undertakes to write her memoir. Iris records and observes her former self from an objective, distanced space, often creating a sense of separation between the current Iris and previous one.

I say 'her' because I don't recall having been present, not in any meaningful sense of the word. I and the girl in the picture have ceased to be the same person. I am her outcome, the result of the life she once lived headlong. (Atwood 95)

Moreover, it may be argued that Iris's task of writing is laborious and painful due to her ailing body, therefore the discordant pace of her two narratives finds expression in this slower pace. Iris writes,

I'm not as swift as I was. My fingers are stiff and clumsy, the pen wavers and rambles, it takes me a long time to form the words. And yet I persist, hunched over as if sewing by moonlight. (Atwood 53)

Atwood makes Iris present two phases of her life through distinct narrative styles, making certain that though both units follow a linear narrative, the pace is distinctly different. The past and present narratives put forward bits of information, like clues, to the reader who attempts to piece them together to find meaning and conclusions; the reader tries to bring together the narrative formed by these two units and the newspaper excerpts in order to understand the remaining fourth unit. The fourth narrative framework appears to be completely removed from the writings and life of Iris. This particular unit speaks through an omniscient narrator who relays the story of an unnamed man and woman who hold clandestine meetings. The narrator in this unit does not attempt to link the main plotline to these characters and all the chapters dedicated to this narrative framework progress independently. The readers suspect that the unnamed man and woman refer to the characters of Alex Thomas and Laura Chase, however by the end of the novel it is revealed that the woman could even refer to Iris herself. 
It is important to note that Atwood presents this unit as excerpts from Laura Chase's novel The Blind Assassin, but its sporadic appearance between the other units pushes the readers to conflate it with the lives of the novel's characters. This unit is perhaps the only narrative which follows a conventional causal progression and a linear narrative: however the conventionality of this unit is upended when the readers realise that the narrator chose to disclose partial truths and deliberately left the characters' identities blurred. An additional narrative is embedded within this unit in which the unnamed man tells an original story to the woman. Set in a dystopian planet called Zychronia the story is about the violent rituals and traditions of the community living there. Although this story evidently has the characteristics of a dystopian fantasy fiction, the readers can locate traces of allegorical references to the lives of Iris and Laura. The physical violence in the story is manifested as corresponding psychological violence outside.

Described as "succulent pieces" good for savouring (Hite 21), these units prove to be interesting, invigorating stories. Although vaguely connected to or in conflict with each other, all the units manage to tell stories which are independently attractive and enjoyable. However, when consumed as a whole, all of the different units together produce a destabilising effect. The reader is forced to confront distinct writing styles and shifting time frames at a rapid pace, causing one to wonder why Atwood chose to work in multiple perspectives and narrative structures. This question is best answered by analysing the overarching consequences of the novel's story and expositions. The revelations brought to the forefront through the course of the novel challenge and disturb the accepted accounts of public history and processes of historiography within the novel's universe. It can be assumed that the unsettling effect caused by challenging the practice of creating history is best understood in conjunction with the confusing, unconventional methods of framing the novel's textual narrative. It may be argued that the unconventional and disorienting narrative frame of the novel reflects the possibility of multiple truths and processes of making history and together created an unstable and unreliable reading experience.

The theme of reclaiming and rewriting history features as the most important theme in the novel. The discordant narrative structure does not suggest a reworking of history from the start of the novel but with progress one realises Iris Chase's true motives behind writing the memoir. Iris describes and records her past life in great detail, often commenting on significant historical 
events from before her birth. The process of writing the memoir also works as a scrutiny of the traditional historical knowledge about the Chase family; Iris's writing provides an alternate or additional source for the knowledge and insight into established historical facts. Within the context of the novel's universe, Iris's reflections on her past become a historiographic piece of writing which threatens to reduce public knowledge to fictional or incorrect information. Both Iris's memoir, as well as Atwood's novel therefore engage in a self-reflexive rewriting of history ${ }^{3}$. This renders the texts an experiment in 'historiographic metafiction' following Linda Hutcheon's concept that historical texts may be critically reworked or used by fiction writers to produce postmodern fiction (Hutcheon 4). Iris draws on her lived experience to revisit her past and challenge its truths, and through her Atwood creates a novel situated between historical facts and fiction. Both Iris and Atwood's accounts depend upon and draw their power from the source of history they contest (Hutcheon 120).

Atwood creates a space for the different perspectives of history to contest each other by employing different narrative structures in the units. The newspaper articles work as the medium of broadcast for important incidentsnews of deaths, exposition of scintillating tabloid gossips, declaration of charity events etc. in the detached and objective manner specific to media reports. Atwood presents these reports as contrasts to Iris's private observations and experiences around them. Iris's stories on the same incidents reveal the way in which public and private experience of the same situation can vastly differ and can often have opposite consequences. One such remarkable example would be the apparent relationship between Iris and her sister-in-law Winnifred. The chapter "Mayfair, 1935" (Atwood 156) - a tabloid coverage of a high society dinner, writes of Winnifred Griffin's celebration of Iris Chase, announcing Iris's imminent engagement to Richard. The festive tone of the tabloid does not reveal the forthcoming tensions between Iris and Winnifred, nor does it comment on Iris's discomfort and humiliation at the dinner. Much later in the novel, in the chapter "The Arcadian Court" (Atwood 281) a fuller account of Iris and Winnifred's relationship is explored. Occurring in the same time frame as the newspaper chapter mentioned above, this chapter lists the ways in which Iris feels belittles and intimidated by Winnifred's castigations of her sense of style

${ }^{3}$ Atwood situates the Chase family within the real and traceable realm of Canadian society. This makes Iris's allusions to her childhood years grounded (partly) within verifiable historical incidents. 
and her mannerisms. The readers recognise the disparity in the two chapters which speak of the same event. Atwood manages to push her readers into a sense of suspense where they are forced to distrust the units focused on the newspaper excerpts. Besides that, Atwood also establishes the idea that public knowledge and its sources can often be predicated on media narratives which invariably exist on superficiality. This suggests that social history built on these sources also remain on the peripheries of the truth but resemble it only slightly. Iris's memoir proves how truths of events are misreported and often suppressed. This is also explained through the chapter "The Toronto Star, 1935" (Atwood 314) in which the news of Laura Chase's disappearance is altered to become a case of misunderstanding. Laura's deliberate escape to an amusement park to hide from Richard is reduced to an unannounced vacation and the mistake of the post. Interestingly, in this chapter as well as in many others including "The Toronto Star, 1945 (Atwood 6), the excerpts conclude with a general comment on the dismal state of civic amenities in the city which reportedly cause confusion and even death ${ }^{4}$. These comments obviously remain quite unconnected with the reality or truths of the incidents, causing the audience to reflect on how the writing of history is also dependent on assumptions by its authors. As Hutcheon states, "History (like realist fiction) is made by its writer even if events are made to seem to speak for themselves" (Hutcheon 66), the creation of history in the novel depend heavily on the knowledge borne by its writers. One of the most significant revelations in the novel is hinged on a deliberate act of creating incorrect public knowledge. Throughout the novel the readers are constantly met with misrepresentation of personal history by the media, resulting in a flawed and untrue public history. Making use of this disparity, Iris's character convinced her contemporary society that Laura Chase was the author of The Blind Assassin. Iris's memoir is directed towards the revelation of her identity as the author of the novel. This at once makes the reader revisit all the moments in the novel which requires Laura to be replaced by Iris. Alex Thomas's unnamed lover (suspected to be Laura) becomes identified as Iris.

In this novel, Atwood works in the significance and potential of personal history and memoir writing as an alternative to traditional historical knowledge. Memoirs, autobiographies, and other production of personal history have often

\footnotetext{
${ }^{4}$ Laura Chase's suicide is summarily presumed to be result of is the frail conditions of the road and streetcar tracks.
} 
been neglected as sources worthy of serious investigation. The scepticism associated with this form of historical writing is slowly fading. Increased attempts at establishing autobiographical writing as a valid source is making the reading of personal history an act of investigation into historical data (Koerber 51, 52). Atwood's intention in the novel may or may not have been an advocacy of alternate historiography. However, the novel's engagement with the discipline through Iris certainly focuses the reader's attention on its possibilities. The novel thus occupies the genre of historiographic metafiction by making the principal character dabble in alternative historiographic writing as well making the narrative challenge and destabilise the dominant ideas of reading truths in traditional accounts of public history.

The act of writing and the reclaiming of identity are the two other most important themes in the novel. Iris laboriously pens her memoir in order to record the history of her family and to finally reveal herself as the author of The Blind Assassin. Writing therefore accords Iris with the sense of control and accomplishment forever denied to her. Reading the story one realises that Iris's life had been largely spent observing and agreeing to those around her-her acceptance of Norval's plans to marry her to Richard, her quiet internalization of Richard's violence towards her, her acquiescence to a secondary position to Winifred regarding Richard's public life, and her silence regarding Richard's management of Laura's institutionalization, all point to a life devoid of significant verbal protestations. This makes Iris's outpouring into the memoir a natural and necessary act, one which endows her with retrospective agency. Iris's motivation behind the memoir and disclosure of her authorial identity is also linked to a question of regaining communication and closure with her grandchild Sabrina. The memoir becomes a powerful and potent source of identity reconstruction for Iris. What is interesting is that by reclaiming her own authorial agency over the novel The Blind Assassin, Iris retracts Laura's posthumous fame as the author of the infamous novel. Iris chooses to publish her novel under Laura's name to protect herself against scandal, and perhaps also to take advantage of Laura's unpredictable (and publicly considered) unstable personality. Some readings of the novel have suggested that Iris's reclaiming of authorial agency is deceptive and her memoir charts untrue stories to win her a place of prominence. "It is theoretically possible she is lying when she claims to be the author of BA and that this act of usurpation is the stage of her sibling rivalry, motivated by the affair with Alex which Laura's novel records" 
(Robinson 355) observations like Robinson's hold ground if one studies Iris as one who felt powerless in contrast to Laura who made multiple attempts to leave the Griffins and finally succeeded by killing herself. A telling proof foe this reading can be found upon reading Iris's observation of Laura speaking about Alex without taking his name,

Alex Thomas never needed a name, for Laura: he was always he, him, his. (Atwood 481)

This may be read as foreshadowing the exclusive use of he/ she pronouns in the text of The Blind Assassin; it could be an indication of Laura writing the text of Iris borrowing Laura's mannerism. Whether Atwood intended to cast Iris as an usurper, or she was truly recording her own life's secrets becomes a question to be assessed by the readers. Iris's complicated self-image and her failure to protect herself and her family could have prompted her to desire power and control over a scandalous narrative: making her claim it as her own. If indeed Iris was not the original author of The Blind Assassin and was merely dislodging her sister, the writing of the memoir becomes an act of double self reflexivity wherein Iris not only rewrites history, but also erases it. However, Atwood certainly intended for the readers to appreciate the act of attaining identity through historiography, something Iris manages irrespective of her being the author or not. Atwood weaves in the theme of identity construction and writing into the larger context of creating and remodelling the dominant structures of historiography.

The novel therefore uses multiple narrative frameworks to build and complicate history and traditional methods of historiography. It emphasises the writing of personal history and shows how it can impact public knowledge and human identities. Atwood exposes the flaws and gaps possibly present in objective narratives of public history and champions memoir writing and the retrospective reclaiming of agency by disenfranchised women. The Blind Assassin is a feat in its self-reflexivity and usage of multiperspective narrative structure.

\section{Works Cited}

Atwood, Margaret. The Blind Assassin, Hachette Book Group, 2000.

Hite, Molly. "Tongueless in Toronto", The Women's Review of Books, Vol. 18, No. 6, 2001. 
Hutcheon, Linda. "Beginning to Theorize the Postmodern", The Canadian Postmodern, 1988.

Kroeber, Duncan. "Truth, Memory, Selectivity: Understanding Historical Work by Writing Personal Histories", Composition Studies, Vol. 41, No. 1, 2013.

Richardson, Brian. "Linearity and Its Discontents: Rethinking Narrative Form and Ideological Valence", College English, Vol. 62, No. 6, 2000.

Robinson, Alan. "Representations of the past in Margaret Atwood's The Blind Assassin", The Modern Language Review, Vol. 101, No. 2, 2006. 